\title{
Resistance exercise combined with KAATSU during simulated weightlessness
}

\author{
N. Kubota, H. Takano, T. Tsutsumi, M. Kurano, H. lida, T. Yasuda, K. Meguro, T. Morita, Y. Sato, \\ S. Kawashima, Y. Yamazaki, H. Ohshima, S. Tachibana, N. Ishii, T. Abe, T. Nakajima
}

Int. J. KAATSU Training Res. 2008; 4: 9-15

Correspondence to:

Toshiaki Nakajima, MD Department of Ischemic

Circulatory Physiology,

KAATSU Training, University

of Tokyo, 7-3-1 Hongo,

Bunkyo-ku, Tokyo, Japan 113

8655

masamasa@pb4.so-net.ne.jp

See end of article for authors' affiliations
The application of a gravity-specific stress (e.g. LBNP), in combination with exercise, prevents cardiovascular deconditioning in space flight. KAATSU training is a method to induce blood pooling in capacitance vessels by restricting venous return (as with LBNP) and which when combined with lowintensity resistance (RE) exercise produces remarkable muscle mass and muscle strength gains. The purpose of this study was to investigate the hemodynamic and neurohumonal responses induced by KAATSU in combination with leg RE (30\% 1 RM), during simulated weightlessness $\left(6^{\circ}\right.$ head-down tilt for $24 \mathrm{~h}, \mathrm{n}=7)$. Following $24 \mathrm{~h}$ bed rest $6^{\circ}$ head-down tilt, body mass was decreased from $75.3 \pm 3.9$ to $73.3 \pm 3.8 \mathrm{Kg}(\mathrm{P}<0.01)$. Blood volume (BV) and plasma volume (PV) were reduced by $-4.4 \pm 1.4 \%$ and $-7.9 \pm 2.5 \%$, respectively. During RE, BV and PV were significantly decreased; the changes with KAATSU induced a lower-body venous pooling, resulting in a sustained decrease in stroke volume (SV; from $77.0 \pm 4.4 \mathrm{ml}$ to $55.9 \pm 5.1 \mathrm{ml} ; \mathrm{P}<0.01$ ) that was comparable to resting SV while standing. Consequently, RE heart rate (HR) was greater with KAATSU. The serum concentrations of plasma renin activity (PRA), vasopressin (ADH), noradrenaline (NOR), and lactate were also significantly elevated during RE with KAATSU as compared to control RE. These hemodynamic and neurohumoral responses following head-down tilt and during RE closely approximate the gravity-specific stress observed with LBNP. Thus, when used in combination with RE, KAATSU may be a useful countermeasure in microgravity.

Key words: KAATSU training, leg press, bed rest, plasma renin activity, noradrenaline

\section{INTRODUCTION}

Astronauts practice $2-3 \mathrm{~h}$ intensive exercise in space. This time-consuming exercise training does not prevent astronauts from cardiovascular deconditioning, and alternative countermeasure strategies are recommended. The most effective regimen is a gravity-simulating stress such as lower body negative pressure (LBNP) or artificial gravity (Güell et al., 1992; Murthy et al., 1994; Watenpaugh et al., 2000; Iwase., 2005) combined with exercise modalities, e.g. treadmill or ergometer. However, these methods are difficult to use in conjunction with resistance exercise.

KAATSU training is a unique technique of lowintensity resistance exercise (RE) training performed in combination with restricted muscle blood flow that results in muscle hypertrophy and muscle strength gains comparable to those observed with highintensity resistance exercise training (Takarada et al. 2000a; b; c; Takarada et al., 2002a,b; Abe et al. 2006; Fujita et al., 2007). The utility of KAATSU training is that it can be applied to most types of exercise. Additionally, KAATSU femoral blood flow restriction induces lower-body venous pooling and reduces venous return (Iida et al., 2007; Nakajima et al., 2008). Thus, the addition of KAATSU to exercise appears to induce an orthostatic stress on the cardiovascular system as observed with LBNP plus exercises, which may be useful in preventing orthostatic intolerance. However, the hemodynamic and neurohumoral responses to exercises combined with KAATSU have not been investigated in a zero gravity environment. The aim of the present study was to investigate hemodynamic and neurohumoral responses to RE with and without KAATSU during the simulated weightlessness using head-down tilt bed rest (Sandler, 1986; Nicogossian, 1994).

\section{MATERIALS AND METHODS Subjects}

Seven healthy males (age, 31.6 \pm 1.1 ; height, $1.76 \pm$ $1.6 \mathrm{~m}$; weight, $75.3 \pm 3.9 \mathrm{~kg}$ ) participated in this study. This study was approved by the institutional review board (IRB) of human research of Japan Aerospace Exploration Agency (JAXA) and the ethics committee of the University of Tokyo. All volunteers had no prior experience with RE and informed consent was obtained prior to the study. The subjects were paid by the grant from JAXA for participating in this study. None of the subjects had any diseases nor took any medications. 


\section{Protocol}

Subjects maintained a 24 -hour period of bed rest in $-6^{\circ}$ head-down tilt position $\left(-6^{\circ}\right.$ bed rest). Transportation and toilet procedures were restricted to the head-down recumbent position. Subjects were allowed to rest on their elbows during meals and could move volitionally but remained horizontal to the bed. Subject's diet, fluid intake, and urine volume were monitored.

After $24 \mathrm{~h}-6^{\circ}$ bed rest, control blood samples were taken. Following bed rest subjects were randomly assigned to one of two groups: one group performed leg press RE without KAATSU, followed by a 2 -h rest interval and then repeated the leg press RE with KAATSU ( 150-160 mmHg cuff pressure; Fig.1). The other group performed leg press RE with KAATSU followed by a 2 -h rest interval and then repeated the leg press RE without KAATSU. Hemodynamic parameters and venous blood samples were collected prior to, during, and following RE. All exercise was performed in the head-down tilt position. Immediately following RE, the KAATSU was released and hemodynamic parameters and blood samples were again collected during a 5-10 min recovery period. After 60 min recovery, the subjects stood up and hemodynamic response was recorded continuously for $5 \mathrm{~min}$ in standing position.

\section{Resistance Exercise Protocol}

Subjects performed leg press RE on a speciallydesigned leg press machine with $-6^{\circ}$ head down tilt. Knee and hip range of joint motion during exercise was 0 to $90^{\circ}\left(0^{\circ}\right.$ being full extension). RE consisted of 4 sets of leg press. The sets consisted of the following repetition pattern; 30 repetitions ( $1 / 3 \mathrm{~s}), 15$ repetitions, 15 repetitions, 15 repetitions. There was a 1 min rest interval between sets. Contraction intensity was $30 \%$ of predetermined one-repetition maximum (1-RM). Individual contraction duration was $3.0 \mathrm{sec}$ with a 1.5:1.5 sec shortening-lengthening contraction duty cycle as controlled by a metronome (40 beats per $\min$ ).

$24 \mathrm{~h}$ bed rest

leg press exercise

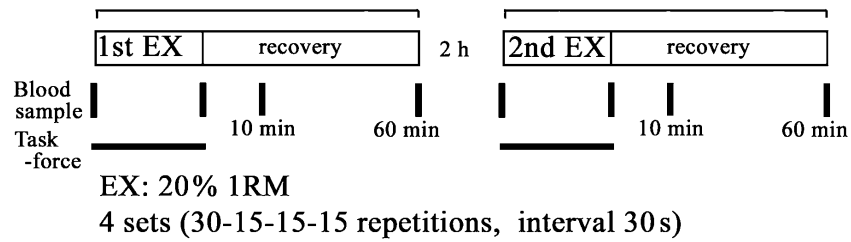

Figure 1. Experimental design. Subjects maintained $6^{\circ}$ head-down tilt position during the bed rest period. After $24 \mathrm{~h}$ at $-6^{\circ}$ bed rest, subjects performed leg press exercises with and without KAATSU (see methods).

\section{KAATSU Blood Flow Restriction}

Femoral blood flow was impaired using the KAATSU technique which also restricts venous blood flow causing pooling of blood in capacitance vessels distal to the cuff and partial occlusion of arterial blood flow (Takano et al., 2005; Iida et al., 2007; Nakajima et al., 2008). KAATSU belts, specifically designed for space flight (65 $\mathrm{mm}$ in width and $650 \mathrm{~mm}$ in length), were applied to the proximal ends of both thighs as near to the hip joint as possible. The cuff pressure was $150 \sim 160 \mathrm{mmHg}$, which was controlled by the KAATSU apparatus.

\section{Cardiovascular Hemodynamics}

Hemodynamic parameters were determined using the Task Force Monitor (CNSystmes Medizintechnik, Graz, Austria; Fortin et al., 1998; Gratze et al., 1998). Analysis included electrocardiogram (ECG), impedance cardiography, beat-to-beat blood pressure by vascular unloading technique (Penaz, 1973) and oscillometric blood pressure. Data were obtained every beat with a $1,000 \mathrm{~Hz}$ sampling rate and used to calculate all hemodynamic parameters in real time. Data included heart rate (HR; bpm), mean arterial blood pressure (MAP; mmHg), systolic blood pressure $(\mathrm{sBP})$, diastolic blood pressure $(\mathrm{dBP})$, stroke volume $(\mathrm{SV} ; \mathrm{ml})$, cardiac output $\left(\mathrm{CO} ; \mathrm{l} \cdot \mathrm{min}^{-1}\right)$ and total peripheral resistance (TPR; dyn $\left.\cdot s \cdot \mathrm{cm}^{-5}\right)$. TPR was calculated in relative units as MAP.CO ${ }^{-1}$, and the calculation of $\mathrm{CO}$ and TPR was as follows:

$$
\begin{aligned}
& \mathrm{CO}=\mathrm{SV} \cdot \mathrm{HR} \\
& \mathrm{TPR}=\mathrm{MAP} \cdot 80 \cdot \mathrm{CO}^{-1}
\end{aligned}
$$

\section{Hormone Metabolite Levels}

An indwelling catheter was inserted into the superficial antebrachial vein of left arm and was maintained patent with a heparin-loc solution. Blood samples were obtained before, $0-1 \mathrm{~min}$ and $10 \mathrm{~min}$ recovery period. Venous blood samples were collected and analyzed for hematocrit, hemoglobin, lactate, noradrenaline, plasma renin activity and vasopressin. For measurement of hemoglobin and hematocrit, 2 $\mathrm{ml}$ of blood was placed into test tubes containing EDTA-2Na. Blood hemoglobin $\left(\mathrm{Hb} ; \mathrm{g} \cdot \mathrm{dl}^{-1}\right)$ was determined by the cyanomethemoglobin method (Coulter hemoglobinometer) and hematocrit (Hct; $\%$ ) by the micro-hematocrit ultra centrifugation technique. Plasma level of lactate was measured at S.R.L. Inc (Tokyo, Japan) by the use of an enzyme system employing lactate oxidase combined with $\mathrm{N}$ ethyl-N-(3-methylphenyl)-N'-acetyl ethylenediamine and an auto-analyzer, HITACHI Type 7170. For hormone determination, blood $(7 \mathrm{ml})$ was placed in test tubes containing $10.5 \mathrm{mg}$ of EDTA-2Na. All samples were kept in ice-cold water and centrifuged 
(3000 rpm) for $10 \mathrm{~min}$ and the plasma stored at $-20^{\circ} \mathrm{C}$ until the assays were performed.

Plasma concentrations of noradrenaline (NOR; lower limit of detection $6 \mathrm{pg} \cdot \mathrm{ml}^{-1}$ ) were measured using high performance liquid chromatography. Plasma renin activity (PRA; lower limit of detection $\left.0.1 \mathrm{ng} \cdot \mathrm{ml}^{-1} \cdot \mathrm{h}^{-1}\right)$ and vasopressin $(\mathrm{ADH}$; lower limit of detection $0.2 \mathrm{pg} \cdot \mathrm{ml}^{-1}$ ) were determined by radioimmunoassay. These assays were completed at commercially available laboratories (SRL Inc., Tokyo, Japan).

Changes in blood and plasma volume (\%) were derived from the following equation (Iida et al., 2007):

$$
\begin{aligned}
& \mathrm{BV}_{\mathrm{B}} \cdot \mathrm{BV}_{\mathrm{A}}^{-1}=\mathrm{Hb}_{\mathrm{A}} \cdot \mathrm{Hb}_{\mathrm{B}}{ }^{-1} \\
& \% \Delta \mathrm{PV}=100 \cdot\left(( \mathrm { Hb } _ { \mathrm { B } } \cdot \mathrm { Hb } _ { \mathrm { A } } ^ { - 1 } ) \cdot \left(\left(1-\mathrm{Hct}_{\mathrm{A}} \cdot 10^{-2}\right) /\right.\right.
\end{aligned}
$$

$$
\left.\left(1-\text { Hct }_{B} \cdot 10^{-2}\right)\right)-100
$$

where $A$ is the initial value and $B$ is the value at the corresponding time.

\section{Data Analysis}

All values are expressed as means \pm S.E.M. Student's paired $t$-test and one-way ANOVA for repeated measures were used, and differences were considered significant if $\mathrm{P}<0.05$.

\section{RESULTS}

Table 1 shows the changes of various parameters following bed rest. Body mass significantly decreased from $75.3 \pm 3.9 \mathrm{Kg}$ (Pre, $0 \mathrm{~h}$ bed rest) to $73.3 \pm 3.8$ $\mathrm{Kg}(\mathrm{n}=7, \mathrm{P}<0.01) 24 \mathrm{~h}$ after $-6^{\circ}$ bed rest. Hct significantly increased from $46.4 \pm 1.2 \%$ to $48.5 \pm$ $0.8 \%(\mathrm{n}=7, \mathrm{P}<0.01)$. Blood volume and plasma volume decreased by $-4.4 \pm 1.4 \%$ and $-7.9 \pm 2.5 \%$ $(\mathrm{n}=7)$, respectively. The urine volume $(2052 \pm 249$ $\left.\mathrm{ml} \cdot \mathrm{d}^{-1}\right)$ markedly exceeded the volume of water intake $\left(1320 \pm 67 \mathrm{ml} \cdot \mathrm{d}^{-1}\right)$, suggesting that the central fluid shift of blood induced by $-6^{\circ}$ bed rest enhanced

Table 1. Changes of various parameters during $24 \mathrm{~h}$ bed rest

\begin{tabular}{|l|c|c|}
\hline Parameters & 0 h bed rest & $24 \mathrm{~h}$ bed rest \\
\hline Body weight $(\mathrm{Kg})$ & $75.3 \pm 3.9$ & $73.3 \pm 3.8^{* *}$ \\
\hline Water balance intake $(\mathrm{ml})$ & ----------------- & $1320 \pm 67$ \\
Urine volume $(\mathrm{ml})$ & ---------------- & $2052 \pm 249$ \\
\hline Hct $(\%)$ & $46.4 \pm 1.2$ & $48.5 \pm 0.8^{*}$ \\
\hline Hb $(\mathrm{mg} / \mathrm{dl})$ & $15.0 \pm 0.3$ & $15.7 \pm 0.3 *$ \\
\hline Blood volume $(\%)$ & ---------------- & $-4.4 \pm 1.4$ \\
\hline Plasma volume $(\%)$ & ---------------- & $-7.9 \pm 2.5$ \\
\hline PRA $(\mathrm{ng} / \mathrm{ml} / \mathrm{h})$ & $1.51 \pm 0.48$ & $0.86 \pm 0.18$ \\
\hline ADH $(\mathrm{pg} / \mathrm{ml})$ & $1.81 \pm 0.26$ & $1.50 \pm 0.12$ \\
\hline NOR $(\mathrm{pg} / \mathrm{ml})$ & $201 \pm 45$ & $157 \pm 24$ \\
Dopamin $(\mathrm{p}$ g/ml $)$ & $7.1 \pm 1.5$ & $5.4 \pm 0.4$ \\
\hline HR $(/ \mathrm{min})$ & $59.2 \pm 4.0$ & $58.9 \pm 3.7$ \\
\hline sBP $(\mathrm{mmHg})$ & $121.9 \pm 5.1$ & $126.0 \pm 5.6$ \\
\hline
\end{tabular}

urine volume, resulting in the loss of plasma volume and an increase in Hct. The serum concentration of PRA and ADH tended to decrease during $-6^{\circ}$ bed rest for $24 \mathrm{~h}$. NOR and dopamine tended to decrease following $-6^{\circ}$ bed rest, but was not statistically significant. HR and sBP did not significantly change.

Fig 2 summarizes the effects of leg press RE with and without KAATSU on hemodynamic parameters. The increase in HR with RE was significantly greater with KAATSU than without KAATSU (Fig. 2A). The peak HR during exercise reached to $107.1 \pm 9.4 \mathrm{bpm}$ (Fig. 2B). sBP (Fig. 2C), dBP, and mBP increased $(\mathrm{P}<0.01)$ during KAATSU exercise, and reached peak values of $154.2 \pm 8.2 \mathrm{mmHg}, 99.2 \pm 6.0 \mathrm{mmHg}$, and $116.1 \pm 6.5 \mathrm{mmHg}$, respectively (Table 2 ). In leg press RE with KAATSU, SV significantly decreased from $77.0 \pm 4.4 \mathrm{ml}$ to $55.9 \pm 5.1 \mathrm{ml}(\mathrm{P}<0.01)$ compared with the exercises without KAATSU (Fig. 2D). The level of SV during KAATSU was approximately equal to that in standing. During leg press RE with KAATSU, CO increased from $4.8 \pm 0.6 \mathrm{l} \cdot \mathrm{min}^{-1}$ to $5.8 \pm$ $0.6 \mathrm{l} \cdot \mathrm{min}^{-1}(\mathrm{P}<0.01$; Fig. 2E). During RE without KAATSU, CO increased from $4.6 \pm 0.4 \mathrm{l} \cdot \mathrm{min}^{-1}$ to $6.0 \pm$
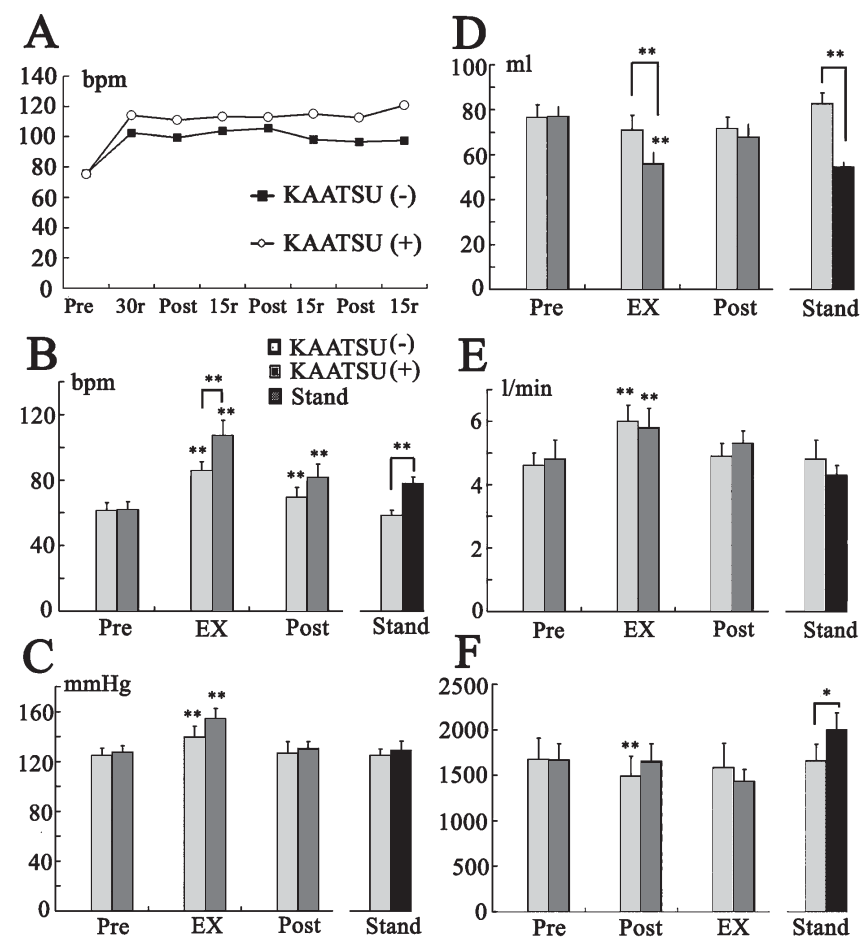

Figure 2. Effects of leg press exercises with and without KAATSU on the hemodynamic parameters (HR (B), sBP (C), SV (D), CO (E), TPR (F)). The changes of HR during exercises are indicated in A. Hemodynamic parameter in control (Pre, $24 \mathrm{~h}$ bed rest), at peak exercise (EX) and $10 \mathrm{~min}$ after the exercises (Post) with and without KAATSU. Effects of standing on these parameters are also indicated before and after standing. $* \mathrm{p}<0.05, * * \mathrm{p}<0.01$ vs. control (pre). Significant differences between exercises with and without KAATSU are also shown. 
Table 2. Hemodynamic responses to acute leg-press exercise in healthy volunteers after 24 h-bed rest

\begin{tabular}{|c|c|c|c|c|}
\hline & & Pre & Peak exercise & Post \\
\hline \multirow[t]{2}{*}{ HR (bpm) } & $(-)$ & $61.3 \pm 4.9$ & $85.6 \pm 5.7 * * 7 * *$ & $69.4 \pm 6.1 * *$ \\
\hline & $(+)$ & $61.9 \pm 4.9$ & $107.1 \pm 9.4 * *$ & $81.7 \pm 8.1 * *$ \\
\hline \multirow[t]{2}{*}{$\mathrm{SV}(\mathrm{ml})$} & $(-)$ & $76.4 \pm 5.7$ & $70.9 \pm 6.6 \quad 7 * *$ & $71.7 \pm 4.9$ \\
\hline & $(+)$ & $77.0 \pm 4.4$ & $55.9 \pm 5.1 * *-$ & $67.7 \pm 5.8$ \\
\hline \multirow[t]{2}{*}{$\mathrm{CO}(1 / \mathrm{min})$} & $(-)$ & $4.6 \pm 0.4$ & $6.0 \pm 0.5^{* *}$ & $4.9 \pm 0.4$ \\
\hline & $(+)$ & $4.8 \pm 0.6$ & $5.8 \pm 0.6^{* *}$ & $5.3 \pm 0.4$ \\
\hline \multirow[t]{2}{*}{$\mathrm{sBP}(\mathrm{mmHg})$} & $(-)$ & $124.8 \pm 6.0$ & $139.6 \pm 8.6^{* *}$ & $126.6 \pm 9.2$ \\
\hline & $(+)$ & $127.5 \pm 4.9$ & $154.2 \pm 8.2 * *$ & $130.3 \pm 5.9$ \\
\hline \multirow[t]{2}{*}{ dBP (mmHg) } & $(-)$ & $79.8 \pm 4.8$ & $90.8 \pm 5.4 * *$ & $79.3 \pm 5.8$ \\
\hline & $(+)$ & $96.4 \pm 4.3$ & $99.2 \pm 6.0 * *$ & $93.5 \pm 4.6$ \\
\hline \multirow[t]{2}{*}{ mBP (mmHg) } & $(-)$ & $92.9 \pm 5.1$ & $105.7 \pm 6.4^{* *}$ & $92.4 \pm 7.1$ \\
\hline & $(+)$ & $77.0 \pm 4.4$ & $116.1 \pm 6.5^{* *}$ & $78.5 \pm 4.3$ \\
\hline TPR & $(-)$ & $1672 \pm 238$ & $1488 \pm 221 * *$ & $1586 \pm 263$ \\
\hline$\left(\right.$ dyne* $\left.s / \mathrm{cm}^{-5}\right)$ & $(+)$ & $1666 \pm 179$ & $1655 \pm 192$ & $1431 \pm 131$ \\
\hline
\end{tabular}

$0.51 \cdot \mathrm{min}^{-1}(\mathrm{P}<0.01)$. The increase in $\mathrm{CO}$ was not statistically different between both exercises. TPR did not change significantly at the peak exercises with and without KAATSU (Fig. 2F).

Fig 3 summarizes the effects of leg press RE with and without KAATSU on neurohumoral parameters. Following RE, there was a significant increase in Hct (Fig.3A) and $\mathrm{Hb}$ which was greater during KAATSU. These changes reflected a significant decrease in BV and PV that was greater during KAATSU (Fig.3B). The increase in lactate concentration after exercise with KAATSU was much higher than that without KAATSU (Fig. 3C). In leg press exercises with KAATSU, NOR increased from $140 \pm 20 \mathrm{pg} \cdot \mathrm{ml}^{-1}$ at rest to $514 \pm 110 \mathrm{pg} \cdot \mathrm{ml}^{-1}(\mathrm{P}<0.01)$ immediately after the exercise, and gradually decreased after the exercise (Fig. 3D). On the other hand, it increased from $131 \pm 16 \mathrm{pg} \cdot \mathrm{ml}^{-1}$ to $239 \pm 47 \mathrm{pg} \cdot \mathrm{ml}^{-1}(\mathrm{P}<0.01)$ in the control exercise. Thus, the increase in NOR concentration attained in the leg press RE with KAATSU was significantly higher than that without KAATSU.

Figs. 3E and $3 \mathrm{~F}$ show the effects of KAATSU on serum concentration of PRA and ADH. PRA significantly increased from $0.7 \pm 0.1 \mathrm{ng} \cdot \mathrm{ml}^{-1} \cdot \mathrm{h}^{-1}$ to $1.3 \pm 0.3 \mathrm{ng} \cdot \mathrm{ml}^{-1} \cdot \mathrm{h}^{-1}$ at $10 \mathrm{~min}$ after the RE without KAATSU $(\mathrm{P}<0.05)$, and ADH also tended to increase from $1.5 \pm 0.1 \mathrm{pg} \cdot \mathrm{ml}^{-1}$ to $1.8 \pm 0.2 \mathrm{pg} \cdot \mathrm{ml}^{-1}$ immediately after the exercises. PRA and ADH were more markedly raised by the application of KAATSU. The leg press exercises combined with KAATSU increased PRA from $1.0 \pm 0.2 \mathrm{ng} \cdot \mathrm{ml}^{-1} \cdot \mathrm{h}^{-1}$ to $2.2 \pm 0.8$ $n g \cdot \mathrm{ml}^{-1} \cdot \mathrm{h}^{-1}(\mathrm{n}=7, \mathrm{P}<0.01)$. In addition, $\mathrm{ADH}$ was also increased during the application of KAATSU (from $1.7 \pm 0.2 \mathrm{pg} \cdot \mathrm{ml}^{-1}$ to $\left.9.2 \pm 3.0 \mathrm{pg} \cdot \mathrm{ml}^{-1}, \mathrm{n}=7, \mathrm{p}<0.01\right)$. In these exercises, CPK did not change significantly (Table 3). In addition, under the simulated weightlessness, all subjects complained no symptoms, and completed the experiments.
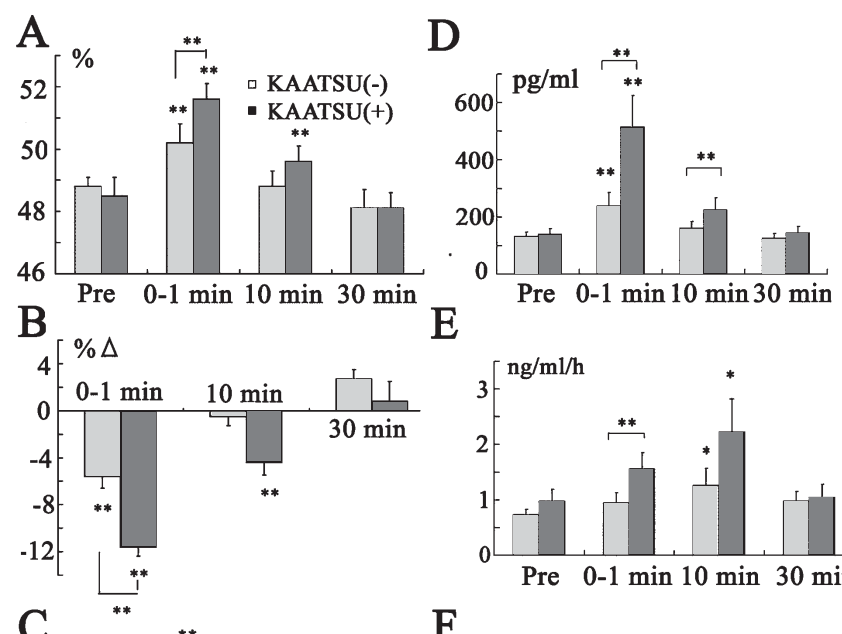

$\mathrm{E}$

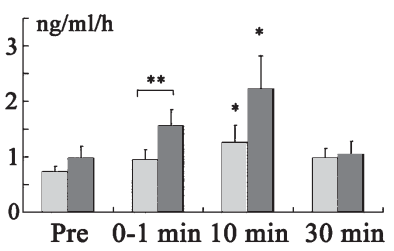

C

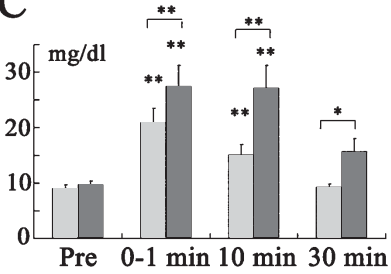

$\mathrm{F}$

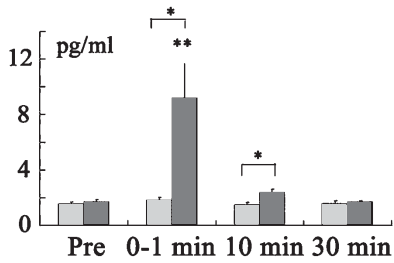

Figure 3. Effects of leg press exercise with and without KAATSU on Hct (A), plasma volume (B), lactate (C), NOR (D), PRA (E), and ADH (F). The changes of plasma volume are shown as compared with the pre level. 
Table 3. Hemostatic responses to acute leg-press exercise in healthy volunteers after 24 h-bed rest

\begin{tabular}{|c|c|c|c|c|c|c|}
\hline & & Pre & $0-1 \mathrm{~min}$ & $10 \mathrm{~min}$ & & $30 \mathrm{~min}$ \\
\hline \multirow[t]{2}{*}{ Hct (\%) } & $(-)$ & $48.8 \pm 0.3$ & $50.2 \pm 0.6 * * \square$ & $48.8 . \pm 0.5$ & \multirow{2}{*}{$\exists *$} & $48.1 \pm 0.6$ \\
\hline & $(+)$ & $48.5 \pm 0.6$ & $51.6 \pm 0.5 * *$ & 49.6. $\pm 0.5^{* *}$ & & $48.1 \pm 0.5$ \\
\hline \multirow[t]{2}{*}{$\mathrm{Hb}(\mathrm{mg} / \mathrm{dl})$} & $(-)$ & $15.9 \pm 0.1$ & $16.3 \pm 0.2 * *$ & $15.9 \pm 0.1$ & \multirow{2}{*}{$\square *$} & $15.7 \pm 0.1$ \\
\hline & $(+)$ & $15.7 \pm 0.2$ & $16.7 \pm 0.2 * *$ & $16.1 \pm 0.1^{* *}$ & & $15.7 \pm 0.1$ \\
\hline \multirow[t]{2}{*}{$\mathrm{BV}(\% \triangle)$} & $(-)$ & - & $-2.9 \pm 0.3 * *$ & $-0.4 \pm 0.4$ & & $1.3 \pm 0.3^{*}$ \\
\hline & $(+)$ & & $-5.9 \pm 0.4 * *$ & $-2.3 \pm 0.7 * *$ & & $0.2 \pm 0.9$ \\
\hline \multirow[t]{2}{*}{$\mathrm{PV}(\% \triangle)$} & $(-)$ & - & $-5.6 \pm 1.0 * *$ & $-0.5 \pm 0.8$ & \multirow{2}{*}{$* *$} & $2.7 \pm 0.8^{*}$ \\
\hline & $(+)$ & & $-11.6 \pm 0.8 * *-$ & $-4.4 \pm 1.1 * *$ & & $0.8 \pm 1.7$ \\
\hline \multirow{2}{*}{$\begin{array}{l}\text { NOR } \\
(\mathrm{pg} / \mathrm{ml})\end{array}$} & $(-)$ & $131 \pm 16$ & $239 \pm 47^{* *} \square$ & $161 \pm 23$ & \multirow[t]{2}{*}{ * } & $126 \pm 17$ \\
\hline & $(+)$ & $140 \pm 20$ & $514 \pm 110 * *-$ & $224 \pm 42$ & & $144 \pm 23$ \\
\hline \multirow{2}{*}{$\begin{array}{l}\text { Lactate } \\
(\mathrm{mg} / \mathrm{dl})\end{array}$} & $(-)$ & $8.9 \pm 0.7$ & $20.9 \pm 2.6 * *$ & $15.0 \pm 1.9^{*}$ & \multirow{2}{*}{$\square * *$} & $9.2 \pm 0.6 \neg$ * \\
\hline & $(+)$ & $9.7 \pm 0.7$ & $27.4 \pm 3.8 * *$ & $27.1 \pm 4.1^{* *}$ & & $15.6 \pm 2.4$ \\
\hline \multirow{2}{*}{$\begin{array}{l}\text { PRA } \\
(\mathrm{ng} / \mathrm{ml} / \mathrm{h})\end{array}$} & $(-)$ & $0.7 \pm 0.1$ & $0.9 \pm 0.2$ & $1.3 \pm 0.3 *$ & \multirow{2}{*}{\multicolumn{2}{|c|}{$\begin{array}{l}1.0 \pm 0.2 \\
1.0 \pm 0.2\end{array}$}} \\
\hline & $(+)$ & $1.0 \pm 0.2$ & $1.6 \pm 0.3$ & $2.2 \pm 0.8^{*}$ & & \\
\hline \multirow{2}{*}{$\begin{array}{l}\mathrm{ADH} \\
(\mathrm{pg} / \mathrm{ml})\end{array}$} & $(-)$ & $1.5 \pm 0.1$ & $1.8 \pm 0.2$ & $1.5 \pm 0.2$ & \multirow{2}{*}{$*$} & $1.6 \pm 0.2$ \\
\hline & $(+)$ & $1.7 \pm 0.2$ & $9.2 \pm 3.0 * *-$ & $2.4 \pm 0.3$ & & $1.7 \pm 0.1$ \\
\hline CPK & $(-)$ & $103 \pm 13$ & $108 \pm 14$ & $103 \pm 13$ & & $102 \pm 13$ \\
\hline (IU/l) & $(+)$ & $105 \pm 14$ & $115 \pm 16$ & $107 \pm 14 *$ & & $103 \pm 14$ \\
\hline
\end{tabular}

$* \mathrm{P}<0.05$ vs. Pre $* * \mathrm{P}<0.01$ vs. Pre $* \mathrm{P}<0.05, * * \mathrm{P}<0.01$ KAATSU (-) vs.

KAATSU (+)

\section{DISCUSSION}

The present study shows that following $24 \mathrm{~h}$ of bed rest with $-6^{\circ}$ head-down tilt, a model simulating microgravity effects on the cardiovascular system, resistance exercise (RE) combined with KAATSU mimic the exercise hemodynamic response to exercise during standing at $1 \mathrm{G}$. Thus, KAATSU combined with resistance exercise appears to stimulate the cardiovascular system during simulated weightlessness and may provide an appropriate countermeasure stimulus for the cardiovascular system associated with weightlessness.

$6^{\circ}$ head-down tilt bed rest (a model used to simulate zero $G$ ) eliminates the normal downward hydrostatic pressure gradients and causes an immediate central fluid shift from lower extremities toward the thoracic-cephalic region (Norsk et al., 1993). The central hypervolemia affects hormonal regulation of fluid excretion and stimulates central cardiac volume receptors, resulting in a loss of plasma volume (Norsk et al., 1993; Duranteau et al., 1995). Some papers have reported that plasma volume (PV) decreases during bed rest within 1-2 d and this lower level was maintained during subsequent bed rest (Volicer et al., 1976; Nixon et al., 1979; Fortney et al., 1991; Norsk et al., 1993; Johansen et al., 1997). In the present study, $24 \mathrm{~h} 6^{\circ}$ head-down tilt bed rest resulted in a total urine volume $\left(2052 \pm 249 \mathrm{ml} \cdot \mathrm{d}^{-1}\right)$ that was in excess of fluid intake $\left(1320 \pm 67 \mathrm{ml} \cdot \mathrm{d}^{-1}\right)$. Blood and plasma volume was decreased by a mean value of $4.4 \%$ and $7.9 \%$, respectively. This fluid volume loss was reflected in the significant decrease in body mass, which was comparable with previous results (Nixon et al., 1979; Gaffney et al., 1985). They reported a significant reduction in PV of up to $500 \mathrm{ml}$ in $24 \mathrm{~h}$. Furthermore, head-down bed rest induces an initial cephalad fluid shift with an inhibition of the renin-angiotensin system and ADH. Hughson et al. (1995) showed a 40\% decrease in PRA after $10 \mathrm{~h}$ head-down tilt. In the present study, concentration of PRA $\left(1.51 \pm 0.48\right.$ to $\left.0.86 \pm 0.18 \mathrm{ng} \cdot \mathrm{ml}^{-1} \cdot \mathrm{h}^{-1}, \mathrm{p}=0.08\right)$ and $\mathrm{ADH}\left(1.81 \pm 0.26\right.$ to $\left.1.50 \pm 0.12 \mathrm{pg} \cdot \mathrm{ml}^{-1}, \mathrm{p}=0.08\right)$ tended to decrease following $24 \mathrm{~h} 6^{\circ}$ head-down tilt bed rest, but were not statistically different. NOR (201 \pm 45 to $157 \pm 24 \mathrm{pg} \cdot \mathrm{ml}^{-1}, \mathrm{p}=0.09$ ) also tended to decrease following $24 \mathrm{~h} 6^{\circ}$ bed rest, which has been reported throughout spaceflight missions and bed rest (Leach et al., 1983; 1985). Thus, it is likely that physiological alterations caused by $6^{\circ}$ head-down tilt bed rest condition observed here effectively mimicked the weightless condition of space flight.

During the simulated weightlessness, we investigated the effects of KAATSU on hemodynamic and neurohumoral responses to leg press RE. The addition of KAATSU to RE induced lower-body venous pooling and reduced venous return, which 
resulted in a sustained decrease of SV comparable to the value observed in standing at rest. Additionally, a greater increase in HR, blood lactate, NOR, PRA, and $\mathrm{ADH}$ concentration was observed when RE was conducted with KAATSU. Thus, the present study shows that the combination of RE and KAATSU during simulated microgravity, elicits hemodynamic and neurohumoral responses that approximate a gravity-specific stress on the cardiovascular system. Thus it appears that RE and KAATSU may provide a unique countermeasure regimen to prevent cardiovascular deconditioning.

Currently, astronauts practice 2-3 h of intensive exercise using treadmill, ergometer and resistance machines. These time-consuming countermeasures cannot completely prevent astronauts from cardiovascular deconditioning. Therefore, alternate countermeasure strategies are necessary. A human centrifuge is a possible candidate, but the centrifuge apparatus is relatively expensive and it is technically laborious to accommodate the apparatus on a space craft. Now, the most effective countermeasure regimen appears to be a gravity-like stress combined with exercise. LBNP has been shown to be a useful method to prevent orthostatic intolerance after space flight, probably through its effect as orthostatic stimulus (Buckey et al., 1996; Güell et al., 1992; Lee et al., 1997; Murthy et al., 1994; Watenpaugh et al., 2000). Supine treadmill exercise combined with LBNP has been reported to maintain submaximal exercise responses such as maximal heart rate, respiratory exchange ratio, and ventilation after bed rest (Lee et al., 1997). In addition, supine exercise in a LBNP chamber $(58 \pm 2 \mathrm{mmHg}$ LBNP) has been reported to maintain aerobic fitness and sprint speed during $15 \mathrm{~d}$ of $6^{\circ}$ head-down bed rest (Watenpaugh et al., 2000). Thus, exercise combined with LBNP appears to provide an effective procedure to stress the cardiovascular system (Hargens, 1994), and may be useful in maintaining upright exercise capacity and prevent orthostatic intolerance during longer bed rest periods or space-flight (Watenpaugh et al., 2000; Perhonen et al., 2001; Schneider et al., 2002). LBNP has been combined with many exercise modalities, e.g. treadmill (Hargens et al., 1991; Murthy et al., 1994), but not resistance-type exercise. This may be important as resistance training specifically promotes muscle enlargement and muscular strength, which are negatively impacted by weightlessness (Akima et al., 2003).

KAATSU training is widely used in Japan (Nakajima et al., 2006) and was originally developed as a novel method for muscle training to increase muscle mass and strength. Under the condition of restricted muscle blood flow with KAATSU, even a short-term and low-intensity exercise bout (treadmill walking, RE, etc) can induce increased muscle mass and muscular strength (Takarada et al. 2000a; b; c; Takarada et al., 2002a,b; Abe et al. 2006). KAATSU training can be applied to most types of exercises such as treadmills, ergometer, and resistance machines. This low-load KAATSU training technique could be easily applied to space flight and utilized by astronauts. Given the previous findings (increased muscle hypertrophy and muscular strength and the present findings), RE with KAATSU appears to provide an interesting combination of effects which may serve as a countermeasure to both cardiovascular and musculoskeletal deconditioning associated with weightlessness. However, the latter needs to be specifically addressed.

\section{References}

Abe T, Kearns CF, Sato Y (2006) Muscle size and strength are increased following walk training with restricted venous blood flow from the leg muscle, Kaatsu-walk training. J Appl Physiol 100: 1460-1466.

Akima H, Ushiyama J, Kubo J, Tonosaki S, Itoh M, Kawakami Y, Fukuoka H, Kanehisa H, Fukunaga T (2003) Resistance training during unweighting maintains muscle size and function in human calf. Med Sci Sports Exerc 35: 655-662.

Buckey JC Jr, Lane LD, Levine BD, Watenpaugh DE, Wright SJ, Moore WE, Gaffney FA, Blomqvist CG. (1996) Orthostatic intolerance after spaceflight. J Appl Physiol 81: 7-18.

Duranteau J, Pussard E, Berdeaux A, Giudicelli JF (1995) Role of the renin-angiotensin system in systemic and regional vascular responses to orthostatic stress in healthy volunteers. Fundam Clin Pharmacol 9: 479487.

Fortney SM, Hyatt KH, Davis JE, Vogel JM (1991) Changes in body fluid compartments during a 28-day bed rest. Aviat Space Environ Med 62: 97-104.

Fortin J, Habenbacher W, Gruellenberger R, Wach P, Skrabal F (1998) Real-time monitor for hemodynamic beat-to-beat parameters and power spectra analyses of the biosignals. In: Proceedings of the 20th Annual International Conference of the IEEE Engineering in Medicine and Biology Society 20: 360-363.

Fujita S, Abe T, Drummond MJ, Cadenas JG, Dreyer HC, Sato Y, Volpi $E$, Rasmussen BB (2007) Blood flow restriction during low-intensity resistance exercise increases $\mathrm{S} 6 \mathrm{~K} 1$ phosphorylation and muscle protein synthesis. J Appl Physiol 103: 903-910.

Gaffney FA, Nixon JV, Karlsson ES, Campbell W, Dowdey AB, Blomqvist CG (1985) Cardiovascular deconditioning produced by 20 hours of bedrest with head-down tilt $\left(-5^{\circ}\right)$ inmiddle-aged healthy men. Am J Cardiol 56: 634-638.

Gratze G, Fortin J, Holler A, Grasenick K, Pfurscheller G, Wach P, Schonegger J, Kotanko P, Skrabal F (1998) A software package for noninvasive, real-time beat-to-beat monitoring of stroke volume, blood pressure, total peripheral resistance and for assessment of autonomic function. Comput Biol Med 28: 121-142.

Güell A, Cornac A, Faurat MM, Gauquelin G, Pary-Le Traon A, Gharib $C$ (1992) Lower body negative pressure as a countermeasure against orthostatic intolerance for long term space flight. Acta Astronaut 27: 103-107.

Hargens AR, Whalen RT, Watenpaugh DE, Schwandt DF, Krock LP (1991) Lower body negative pressure to provide load bearing in space. Aviat Space Environ Med 62: 934-937.

Hargens AR (1994) Recent bed rest results and countermeasure development at NASA. Acta Physiol Scand 616: 103-114. 
lida H, Kurano M, Takano H, Kubota N, Morita T, Meguro K, Sato $Y$, Abe T, Yamazaki Y, Uno K, Takenaka K, Hirose K, Nakajima T (2007) Hemodynamic and neurohumoral responses to the restriction of femoral blood flow by KAATSU in healthy subjects. Eur J Appl Physiol 100: 275285.

Iwase S. Effectiveness of centrifuge-induced artificial gravity with ergometric exercise as a countermeasure during simulated microgravity exposure in humans. Acta Astronaut 2005; 57: 75-80.

Johansen LB, Gharib C, Allevard AM, Sigaudo D, Christensen NJ, Drummer C, Norsk P (1997) Haematocrit, plasma volume and noradrenaline in humans during stimulated weightlessness for 42 days. Clin Physiol 17: 203-210.

Leach CS, Altchuler SI, Cintron-Trevino NM (1983) The endocrine and metabolic responses to space flight. Med Sci Sports Exerc 15: 432-440.

Leach CS, Vernikos-Danellis J, Krauhs JM, Sander H (1985) Endocrine and fluid metabolism in males and females of different ages after bedrest, acceleration, and lower body negative pressure. Houston, TX: NASA Johnson Space Center, (NASA technical Memorandum 58270)

Lee SM, Bennett BS, Hargens AR, Watenpaugh DE, Ballard RE, Murthy G, Ford SR, Fortney SM (1997) Upright exercise or supine lower body negative pressure exercise maintains exercise responses after bed rest. Med Sci Sports Exerc 29: 892-900.

Murthy G, Watenpaugh DE, Ballard RE, Hargens AR (1994) Exercise against lower body negative pressure as a countermeasure for cardiovascular and musculoskeletal deconditioning. Acta Astronaut 33: 89-96.

Nakajima T, Kurano M, lida H, Takano H, Oonuma H, Morita T, Meguro K, Sato Y, Nagata T, Kaatsu Training Group (2006) Use and safety of KAATSU training: Results of a national survey. Int J KAATSU Training Res 2: 5-14.

Nakajima T, lida $H$, Kurano $M$, Takano $H$, Morita T, Meguro $K$, Sato $Y$, Yamazaki Y, Kawashima S, Ohshima H, Tachibana S, Ishii N, Abe T (2008) Hemodynamic responses to simulated weightlessness of $24 \mathrm{~h}$ head-down bed rest and KAATSU blood flow restriction. Eur J Appl Physiol (in press)

Nicogossian AE (1994) Microgrvity simulations and analogues. In: Space Physiology and Medicine, $3^{\text {rd }}$ edn (ed. Nicogossian A.E., LeachHuntoon C. \& Pool S.L.), pp.363-371

Nixon JV, Murray RG, Bryant C, Johnson RL Jr, Mitchell JH, Holland OB, Gomez-Sanchez C, Vergne-Marini P, Blomqvist CG. (1979) Early cardiovascular adaptation to stimulated zero gravity. J Appl Physiol 46: 541-548.

Norsk P, Stadeager C, Johansen LB, Warberg J, Bie P, Foldager N, Christensen NJ (1993) Volume-homeostatic mechanisms in humans during a 12-h posture change. J Appl Physiol 75: 349-356.

Penaz J (1973) Photoelectric measurement of blood pressure, volume and flow in the finger. Digest of the $10^{\text {th }}$ International Conference on Medical and Biological Engineering, Dresden.

Perhonen MA, Franco F, Lane LD, Buckey JC, Blomqvist CG, Zerwekh JE, Peshock RM, Weatherall PT, Levine BD (2001) Cardiac atrophy after bed rest and spaceflight. J Appl Physiol 91: 645-653.
Sandler H (1986) Cardiovascular effects of inactivity. In: Inactivity: Physiological Effects (ed. Sandler H. \& vernikos-Daniellis J.), Academic Press, London, pp. 11-47,.

Schneider SM. Watenpaugh DE, Lee SM, Ertl AC, Williams WJ, Ballard RE, Hargens AR (2002) Lower-body negative-pressure exercise and bedrest-mediated orthostatic intolerance. Med Sci Sports Exerc 34: 14461453.

Takano H, Morita T, lida H, Asada K, Kato M, Uno K, Hirose K, Matsumoto A, Takenaka K, Hirata Y, Eto F, Nagai R, Sato Y, Nakajima T (2005) Hemodynamic and hormonal responses to a short-term lowintensity resistance exercise with the reduction of muscle blood flow. Eur $\mathrm{J}$ Appl. Physiol 95: 65-73.

Takarada $Y$, Nakamura $Y$, Aruga S, Onda T, Miyazaki S, Ishii N (2000a) Rapid increase in plasma growth hormone after low-intensity resistance exercise with vascular occlusion. J Appl Physiol 88: 61-65.

Takarada Y, Takazawa H, Sato Y, Takebayashi S, Tanaka Y, Ishii N (2000b) Effects of resistance exercise combined with moderate vascular occlusion on muscle function in humans. J Appl Physiol 88: 2097-2106.

Takarada Y, Takazawa H, Ishii N (2000) Applications of vascular occlusion diminish disuse atrophy of knee extensor muscles. Med Sci Sports Exerc 32: 2035-2039.

Takarada Y, Sato Y, Ishii N (2002a) Effects of resistance exercise combined with vascular occlusion on muscle function in athletes. Eur $J$ Appl Physiol 86: 308-314.

Takarada Y, Ishii N (2002b) Effects of low-intensity resistance exercise with short interest rest period on muscular function in middle-aged women. J Strength Cond Res 16: 123-128.

Volicer L, Jean-Charles R, Chobanian AV (1976) Effects of head-down tilt on fluid and electrolyte balance. Aviat Space Environ Med 47: 10651068.

Watenpaugh DE, Ballard RE, Schneider SM, Lee SM, Ertl AC, William $J M$, Boda WL, Hutchinson KJ, Hargens AR (2000) Supine lower body negative pressure exercise during bed rest maintains upright exercise capacity. J Appl Physiol 89: 218-227.

\section{Authors' affiliations}

N. Kubota, H. Takano, M. Kurano, H. lida, T. Yasuda, K. Meguro, Y. Sato, T. Nakajima, Department of Ischemic Circulatory Physiology, KAATSU Training, University of Tokyo, Tokyo, Japan

T. Morita, Department of Cardiovascular Medicine, University of Tokyo, Tokyo, Japan

S. Kawashima, H. Ohshima, S. Tachibana, Japan Aerospace Exploration Agency, Tsukuba, Japan

Y. Yamazaki, Japan Manned Space Systems Corporation, Tokyo, Japan T. Abe, Department of Human and Engineered Environmental Studies, Graduate School of Frontier Science, The University of Tokyo, Chiba, Japan

N. Ishii, Department of Life Sciences, Graduate School of Arts and Sciences, University of Tokyo, Tokyo, Japan

N. Kubota, T. Tsutsumi, Division of Cardiology, Showa University Fujigaoka Hospital, Japan 
